Copyright (C) 2021 University of Bucharest Printed in Romania. All rights reserved

ISSN print: $1224-5984$

ISSN online: $2248-3942$
Rom Biotechnol Lett. 2021; 26(2): 2375-2383

doi: $10.25083 / \mathrm{rbl} / 26.2 / 2375.2383$

Received for publication, September, 20, 2020

Accepted, December, 4, 2020

Original paper

\title{
Assessment of vitamin content in different types of romanian cheese
}

\author{
EVELINA GHERGHINA ${ }^{1,3}$, FLORENTINA ISRAEL-ROMING ${ }^{1}$, DANIELA BĂLAN ${ }^{*}$, \\ GABRIELA LUŢĂ ${ }^{1}$, AGLAIA POPA ${ }^{1}$, MARTA ZACHIA ${ }^{2}$
}

${ }^{1}$ University of Agronomical Sciences and Veterinary Medicine Bucharest, Romania

${ }^{2}$ National Research and Development Institute for Food Bioresources-IBA Bucharest, Romania

${ }^{3}$ Centre for Applied Biochemistry and Biotechnology BIOTEHNOL Bucharest, Romania

\begin{abstract}
In recent years there was a preference for healthy natural products hence an increased interest in functional food including fermented dairy products occurred. Dairy products contain nutrients essential for health, of which vitamins could help reduce the risk of certain diseases. Cheese is a highly nutritious food that can play an important role in a wellbalanced diet. The aim of this research was to investigate the vitamin composition of various types of cheese and to evaluate the vitamins intake provided by cheese as part of the daily diet. The determinations were performed on traditional Romanian cheese, meaning cow, sheep, goat and buffalo Telemea and some Kashkaval types purchased from local supermarkets. The samples were subjected to vitamins B1, B2, B12, A and E analysis using spectrofluorometric, spectrophotometric, HPLC and microbiological methods. The results showed a higher content of vitamins B2 and E in Telemea cheese while Kashkaval types were distinguished for vitamin B1, B12 and A. Regarding the vitamin content depending on raw material used for obtaining the different types of cheese, those made from goat milk recorded the highest level of the analyzed vitamins, followed by those from sheep milk, while lowest amounts were found in products obtained from cow.
\end{abstract}

Keywords Cheese, Kashkaval, Telemea, vitamins.

To cite this article: GHERGHINA E, ROMING FI, BĂLAN D, LUȚĂ G, POPA A, ZACHIA M. Assessment of vitamin content in different types of romanian cheese. Rom Biotechnol Lett. 2021; 26(2): 2375-2383. DOI: 10.25083/rb1/26.2/2375.2383 


\section{Introduction}

Lately the requirement of modern consumers for health-promoting natural products increases the interest in biofunctional foods, containing probiotics, prebiotics, vitamins and minerals such as diverse fermented dairy products (SANDERS, 1998; STANTON, 2005).

Dairy products contain many biochemical compounds that are essential for health, of which vitamins are some of the nutrients that keep the body functioning properly and could help reduce the risk of certain diseases (KWAK, 2012; LINARES, 2017).

Cheese is a product obtained by coagulation of milk that gives a solid phase (coagulum or curd) and a liquid phase (whey). The curd obtained by draining will turn into cheese and may be salted, fermented and/or ripened for certain time in order to develop the flavor and texture characteristic of the cheese variety.

Cheese is a highly nutritious food that can play an important role in a well-balanced diet. The nutritional value of cheese depends largely on its composition which is determined during the production process. So, draining of curd leads to a loss of proteins (with the whey) and lactose; also most of the milk water-soluble vitamins remain into the whey during curd manufacture. Skimming of milk induces a loss of lipids therefore of fat-soluble vitamins, while fermentation and ripening lead to enrichment in group B vitamins.

Consequently, the main vitamins present in the cheese are the fat-soluble vitamins (A, D and E) retained by the curd, which contains $90 \%$ of the milk fat. As to the water-soluble vitamin content, it varies significantly from one cheese to another depending on microbial synthesis that occurs in cheese during ripening (FOX, 2017). Some bacterial strains as Lactobacillus sp. and Bifidobacterium sp. involved in dairy products fermentation can provide an additional source of $\mathrm{B}$ vitamins (thiamin, riboflavin, cobalamin, folate and biotin) during dairy fermentation (LEVIT, 2016; VAN WYK, 2011; LAIÑO, 2013). Also the dairy propionibacteria, especially $P$. freudenreichii ssp. shermanii, the main component of ripening flora in Swisstype cheeses, are used for the production of vitamin B12 and there is an increasing interest in their potential use as probiotics (GARDNER, 2005; VOROBJEVA, 2008; RABAH, 2017).

Vitamins are involved in intermediary metabolism as cofactors in numerous enzymatic reactions or in nonenzymatic physiological functions such as the visual process (vitamin A), as antioxidants (carotenoids, vitamins $\mathrm{E}, \mathrm{C}$ and B2), in regulation of calcium metabolism (vitamin D) and in haematopoiesis (vitamin B12, folate and vitamin B6) (ÖSTE, 1997).

Most vitamins are present in a variety of foods, however vitamin deficiencies still exist in many countries as a result of insufficient food intake and because of unbalanced diets. Moreover, B-group vitamins, usually present in many foods, are easily destroyed during cooking and food processing, leading also to insufficient amounts in the daily diet.
For the above reasons, several types of Romanian cheese named Telemea and Kashkaval were selected for a vitamin content analysis.

Telemea is a traditional Romanian cheese typically made of sheep milk, but nowadays the term is used also for cheese made out of cow milk, and in some cases of goat, or buffalo's milk (BRATU, 2012). Since 2005, the name Telemea is a protected designation of origin product of Romania. Similar to the Greek feta or Turkish teleme, Romanian Telemea can have high water content, that gives them a soft, creamy texture and a strong, spicy flavor. Alternatively, it may be left to mature in brine that makes it crisper, more flavored and salty and it can be kept longer in very concentrated brine.

Kashkaval is a semi-hard, yellow cheese made of cow milk, sheep milk or both. It belongs to the family of pasta filata cheeses (SANTA, 2014) that is made by giving the curd a hot bath during the production process and is allowed to age for six months when developing a piquant, taste. Kashkaval is particularly popular in Eastern Europe, where is used as a generic term for all kinds of yellow cheeses.

The aim of this research was to investigate the vitamin composition of various types of Telemea and Kashkaval of different provenance and to evaluate the vitamins intake provided by cheese as part of the daily diet. Regulation (EU) No 1169/2011 of the European Parliament and of the Council on the provision of food information to consumers contains specification regarding recommended daily allowances for vitamins. In this context, as some dairy products have a significant intake of vitamins, consumers looking for healthy foods should be informed about this, especially as public interest in functional foods has increased.

\section{Materials and Methods}

\section{Samples}

Several types of traditional Romanian cheese, meaning cow, sheep, goat and buffalo Telemea were selected for vitamins content determination. In addition the same analysis were made on some Kashkaval types made from cow milk: Penteleu (cow 1), Rucar (cow 2), Dalia (cow 3); sheep milk: sheep 1, Dobrogea (sheep 2) and one smoked type of Kashkaval (obtained also from cow milk). Dairy products were purchased from local supermarkets.

Analysis of vitamins B1, B2, B12, vitamin A (expressed as $\beta$-carotene), vitamin $\mathrm{E}$ (expressed as $\alpha$-tocopherol) was performed in triplicate. The cheese samples were finely crushed and an average sample was weighed for each type. The results were expressed per $100 \mathrm{~g}$ of fresh weight (FW).

\section{Analysis methods}

\section{Determination of vitamin B1 content}

Sample preparation. A weighed amount of sample was digested with sulphuric acid on a boiling water bath and subsequently treated with an enzymatic complex containing phosphatase and protease for releasing the thiamin from the natural ester and protein bonds. 
Analysis method. Thiamin content was analysed using a fluorometric method based on the oxidation of thiamin with oxidizing reagent (potassium ferricyanide in alkaline solution) to fluorescent thiochrome which was extracted with isobutyl alcohol. The intensity of fluorescence of the isobutyl alcohol extract was compared with that of the standard solution $(100 \mu \mathrm{g} / \mathrm{ml}$ thiamin $)$. Also a blank (control) prepared by adding of sodium metabisulphite in the sample was used. The intensity of fluorescence was measured with a JASCO FP-6300 spectrofluorometer and the fluorescence value of the blank test was subtracted from that of the sample extract. Fluorometric analysis of thiamin involve $370 \mathrm{~nm}$ as the excitation wavelength and $460 \mathrm{~nm}$ as the florescence emission wavelength (YANG, 2015).

\section{Determination of vitamin $\mathrm{B} 2$ content}

Sample preparation. Fluorometric determination of vitamin B2 was performed after extraction in acidic medium under heating. Acid hydrolysis must be followed by enzymatic hydrolysis which is performed in order to release riboflavin from the FAD and FMN enzymes present in the analyzed product. Therefore digestion with sulphuric acid on a boiling water bath $(15 \mathrm{~min})$ and subsequently enzymatic treatment with phosphatase and protease were applied.

Analysis method. Vitamin B2 content was fluorometric measured after extraction in isobutyl alcohol. The intensity of fluorescence of the isobutyl alcohol extract was compared with that of the standard solution $(100 \mu \mathrm{g} / \mathrm{ml}$ riboflavin). Also a blank (control) was prepared by adding of sodium metabisulphite in the sample. The intensity of fluorescence was measured with a JASCO FP-6300 spectrofluorometer and fluorescence value of the blank test was subtracted from that of the sample extract. This method is applicable to dairy products for vitamin B2 content ranging from very low (minimum $5 \mathrm{ppm}$ ) to very high values. Analysis of riboflavin by fluorometric method was made at $450 \mathrm{~nm}$ as the excitation wavelength and $525 \mathrm{~nm}$ as the fluorescence emission wavelength (YANG, 2015).

\section{Determination of vitamin B12 content}

Total content of vitamin B12 was measured according to the AOAC 960.46 microbiological method using the VitaFast Vitamin B12 test kit (produced by R-Biopharm). Vitamin B12 was extracted from a homogenized sample and the extract is diluted. The diluted extract and the standards were applied to the wells of a microtiter plate coated with Lactobacillus delbrueckii subsp. lactis (leichmannii). The growth of the bacteria is dependent on the vitamin content and induces turbidity proportional to the amount of vitamin present in the culture medium. The measurement of the turbidity was performed with a microplate reader, at $630 \mathrm{~nm}$.

Determination of vitamin A content (expressed as $\beta$-carotene)

A spectrophotometric method adapted to the complex matrix of dairy products was used to determine the amount of vitamin A which was quantified as $\beta$-carotene (BALAN, 2014).

Samples preparation. The samples were treated with alcoholic $\mathrm{KOH}$ solution in order to perform a grease saponification.

Extraction of $\beta$-carotene. The extraction of $\beta$-carotene was performed in separatory funnels with portions of acetone till the last extract became colorless. The acetonic extracts were collected in another separatory funnel and hexan were added so two layers are separated. The clear extract of $\beta$-carotene (superior layer) was collected and the absorbance was measured at $450 \mathrm{~nm}$. Quantification was realized with a calibration curve prepared with $\beta$-carotene solution. The limit of quantification was $0.2 \mu \mathrm{g} / \mathrm{ml}$ $\beta$-carotene.

\section{Determination of vitamin $E$ (a-tocopherol) content}

The content was analyzed using a reversed phase HPLC with UV detection method (GHERGHINA et al, 2015).

Sample preparation. Saponification of samples with $\mathrm{KOH}$ ethanolic solution was performed at $80^{\circ} \mathrm{C}$, with continuous agitation, for 15 minutes. Ascorbic acid was used for preventing vitamin E oxidation. After saponification, $\alpha$-tocopherol was extracted with isooctane. The non-polar solvent was evaporated at $45^{\circ} \mathrm{C}$ in a centrifugal evaporator and vitamin $\mathrm{E}$ was solubilized in methanol.

Analysis method. Separation of tocopherols was carried out by RP-HPLC method, using a Waters Alliance system, with UV detection. The separation was performed with C8 Symmetry column and a mobile phase consisting in methanol + acetonitrile + water solution. The data was achieved and processed with EMPOWER 2.0 specialized software. Calibration curve was obtained using $56.22 \mu \mathrm{g} / \mathrm{ml} \alpha$-tocopherol standard solution.

Statistical analyses. All measurements were carried out in triplicate, and the results are presented as means \pm S.D. The mean values of the quantitative variables were compared by Analysis of Variance (ANOVA) considering the differences as significant for $\mathrm{p} \leq 0.05$.

\section{Results}

\section{Assessment of vitamin B1 (thiamin) in the analyzed type of cheese}

In Telemea type cheeses, vitamin B1 content was found between $6.04 \pm 0.21 \mu \mathrm{g} / 100 \mathrm{~g} \mathrm{FW}$ (cow Telemea) and $21.49 \pm 0.95 \mu \mathrm{g} / 100 \mathrm{~g} \mathrm{FW}$ (goat Telemea) (Figure 1).

There was a significant difference in the content of vitamin B1 between the two samples of Telemea obtained from goat milk, which may indicate that not only the breed of the animal that provides the raw material (milk) influences the concentration of vitamin B1 in the final product, but also other factors (food, animal age, season, milk processing). 


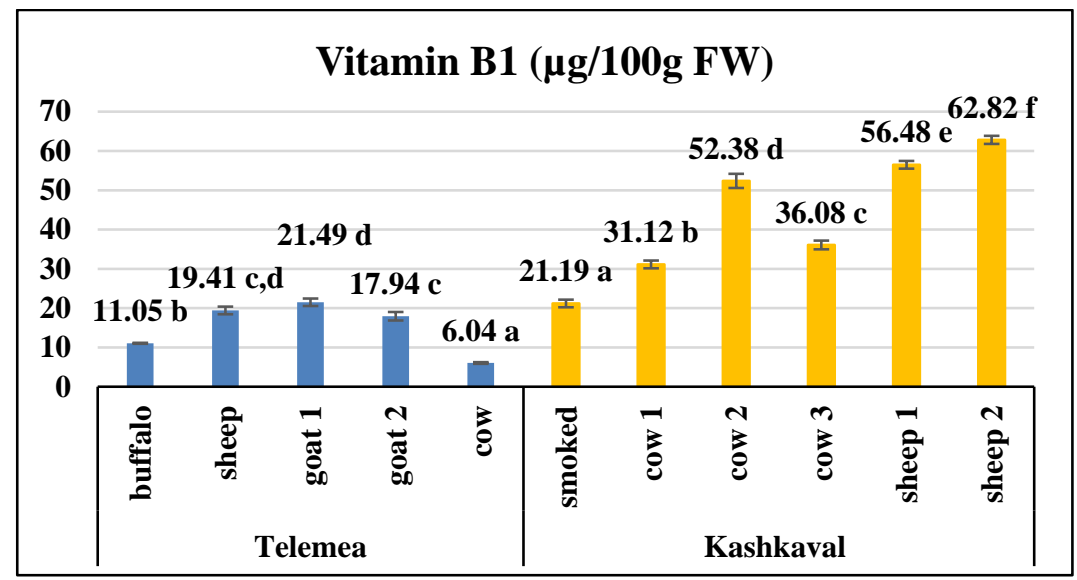

Figure 1. Content in vitamin B1 in the selected types of cheese

Note: For each group averages $( \pm S D ; n=3)$ noted with the same letters are not significantly different $(p \leq 0.05)$

For Kashkaval types, the values of vitamin B1 ranged between $21.19 \pm 0.97$ in smoked Kashkaval and 62.82 \pm $1.03 \mu \mathrm{g} / 100 \mathrm{~g}$ FW (Figure 1) in Kashkaval type Dobrogea (sheep 2), therefore higher than those determined in Telemea cheese.

\section{Assessment of vitamin B2 (riboflavin) in the analyzed type of cheese}

Analysis of local cheeses indicated that riboflavin content reached values around 10 times higher than those of vitamin B1 for all analyzed dairy products (Figure 2). For Telemea cheeses, the lowest value of vitamin B2 content was obtained for buffalo Telemea (187.12 \pm $9.04 \mu \mathrm{g} / 100 \mathrm{~g} \mathrm{FW}$ ), while goat Telemea achieved the highest value $(1068.22 \pm 24.15 \mu \mathrm{g} / 100 \mathrm{~g} \mathrm{FW})$. According to the study conducted by Górska-Warsewicz (2019), dairy products are a very important source of riboflavin, the author reporting an average value of $3.79 \mathrm{mg} / 100 \mathrm{~g}$ riboflavin in the studied types of cheeses.

As in the case of vitamin B1, there was a significant difference between the two types of cheese obtained from goat milk in terms of vitamin B2 content, which can be explained by their different origin as a geographical area.

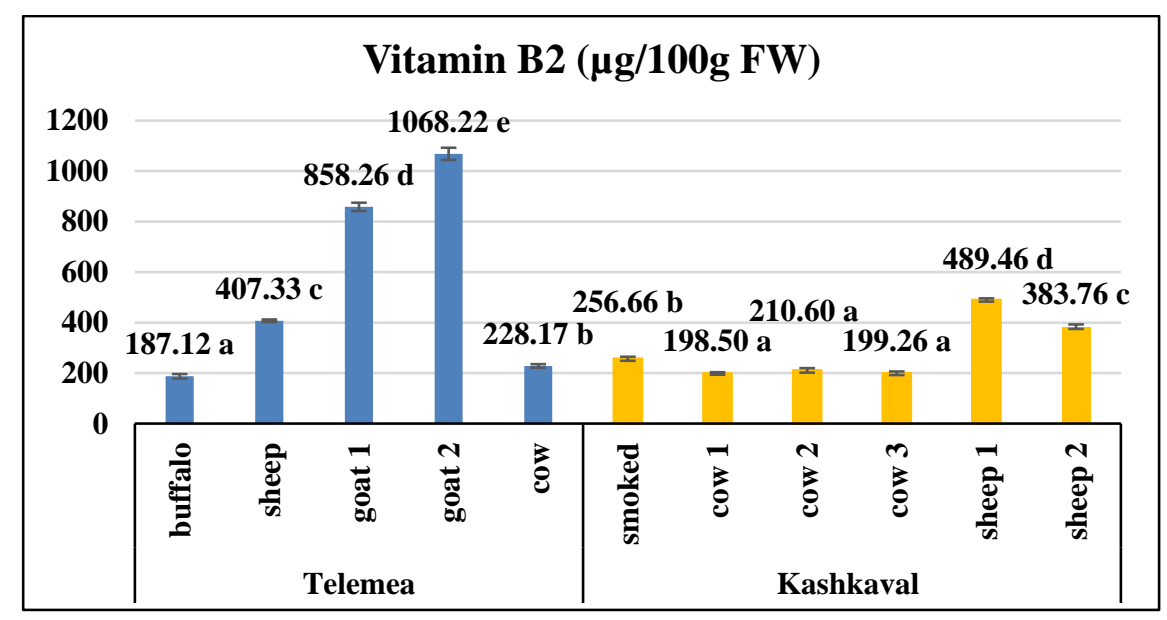

Figure 2. Content in vitamin B2 in the selected types of cheese

Note: For each group averages $( \pm \mathrm{SD} ; \mathrm{n}=3)$ noted with the same letters are not significantly different $(\mathrm{p} \leq 0.05)$

For the Kashkaval types, vitamin B2 amounts ranged from $198.50 \pm 4.97$ to $489.46 \pm 6.41 \mu \mathrm{g} / 100 \mathrm{~g} \mathrm{FW}$ (Figure 2). The highest value was found for cheese made from sheep milk, and the lowest for Penteleu cheese (cow 1). No significant differences were observed between the Kashkaval types obtained from cow milk, independent of their brand or their origin (Penteleu, Rucar, Dalia).

\section{Assessment of vitamin B12 (cobalamin) in the analyzed type of cheese}

In the case of Telemea type cheeses, the recorded content of vitamin B12 was between $0.10 \pm 0.01 \mu \mathrm{g} / 100 \mathrm{~g}$ FW (in goat Telemea) and $0.49 \pm 0.02 \mu \mathrm{g} / 100 \mathrm{~g} \mathrm{FW}$ (in cow Telemea) (Figure 3). There are no significant differences between the two types of goat Telemea. 


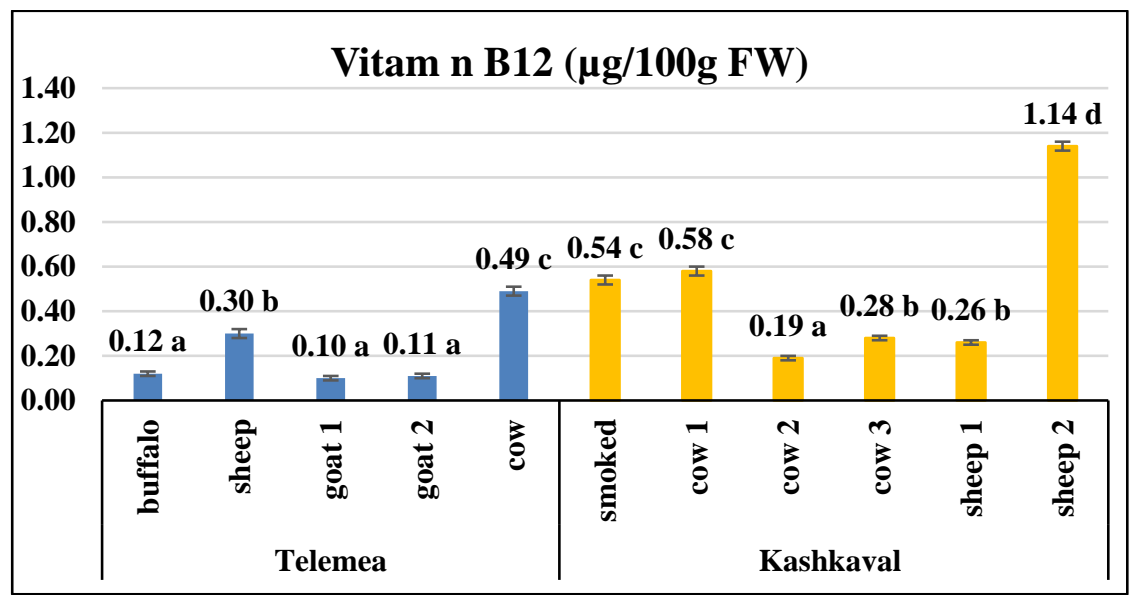

Figure 3. Content in vitamin B12 in the selected types of cheese

Note: For each group averages $( \pm \mathrm{SD} ; \mathrm{n}=3)$ noted with the same letters are not significantly different $(\mathrm{p} \leq 0.05)$

The amounts of vitamin B12 were lower than those obtained for Kashkaval type products: between $0.19 \pm$ $0.01 \mu \mathrm{g} / 100 \mathrm{~g} \mathrm{FW}$ in Rucar Kashkaval (cow 2), and $1.14 \pm 0.02 \mu \mathrm{g} / 100 \mathrm{~g} \mathrm{FW}$ in Dobrogea Kashkaval (sheep 2).

The analysis of cobalamin indicate that the results are related with the vitamin $\mathrm{B} 12$ in milk, but also with the processing method tipical for each variety of Kashkaval.

Mean vitamin B12 concentrations in different cheese products is reported by the national food composition databases of Denmark, Switzerland and Canada between 0.34-3.34 $\mu \mathrm{g} / 100 \mathrm{~g}$ (GILLE, 2015).

\section{Assessment of vitamin A (expressed as $\beta$-carotene) in the analyzed type of cheese}

The obtained results showed low values for the $\beta$-carotene content (Figure 4) compared to group B vitamins. Vitamin A is partially influenced by both the original milk composition and the obtaining technology (LUCAS, 2006). A small proportion of the retinol and carotenoids is associated with whey proteins (PUYOL, 1991) and/or concentrated in the milk fat globule membrane (ZAHAR, 1995). As a result, some amount of these components could be lost with the whey during cheese-making or by skimming of milk, while fermentation and ripening of curd induce an enrichment in group B vitamins provided by certain bacterial strains (Lactobacillus sp., Bifidobacterium sp.) involved in dairy products obtaining.

For Telemea cheeses the $\beta$-carotene content varied between $3.68 \pm 0.91 \mu \mathrm{g} / 100 \mathrm{~g} \mathrm{FW}$ in buffalo Telemea and $29.39 \pm 1.47 \mu \mathrm{g} / 100 \mathrm{~g} \mathrm{FW}$ in cow Telemea (Figure 4). Also the Telemea obtained from sheep and goat milk recorded low amounts of vitamin A compare to the cow Telemea, which was found almost three times richer in vitamin A.

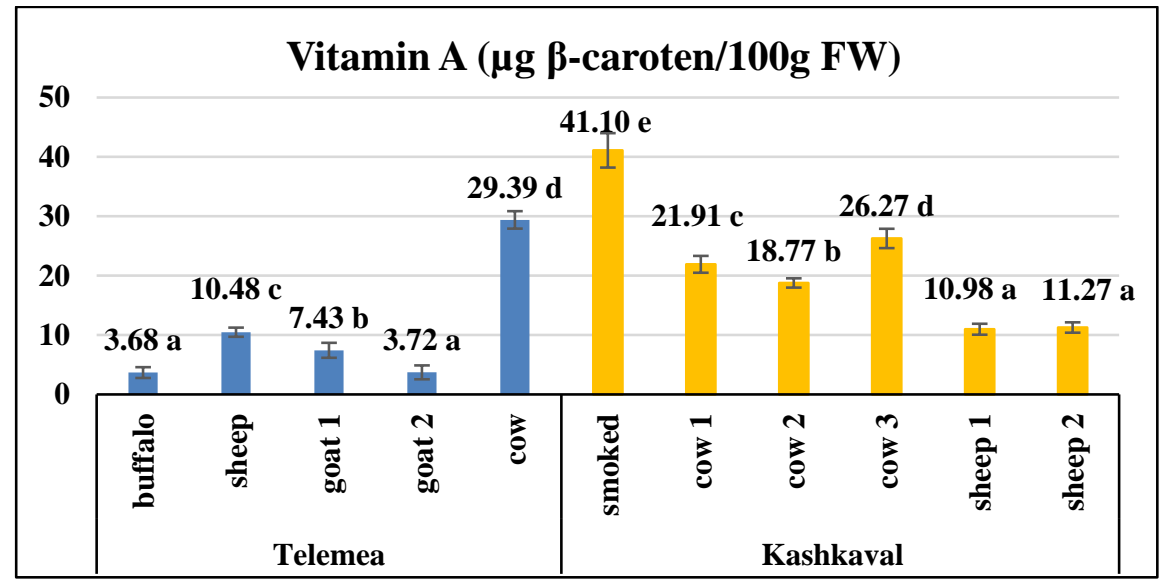

Figure 4. Content in vitamin $A$ in the selected types of cheese

Note: For each group averages $( \pm S D ; n=3)$ noted with the same letters are not significantly different $(p \leq 0.05)$

For Kashkaval types, the amounts of $\beta$-carotene are generally higher than for Telemea cheese, reaching values between $10.98 \pm 0.92 \mu \mathrm{g} / 100 \mathrm{~g}$ FW in sheep Kashkaval and $41.10 \pm 2.90 \mu \mathrm{g} / 100 \mathrm{~g} \mathrm{FW}$ in smoked Kashkaval.
The highest value was registered in smoked Kashkaval so it seems that the content in $\beta$-carotene was not affected by the smoking process but further investigations on this topic are necessary. 


\section{Assessment of vitamin E ( $\alpha$-tocopherol) in the analyzed type of cheese}

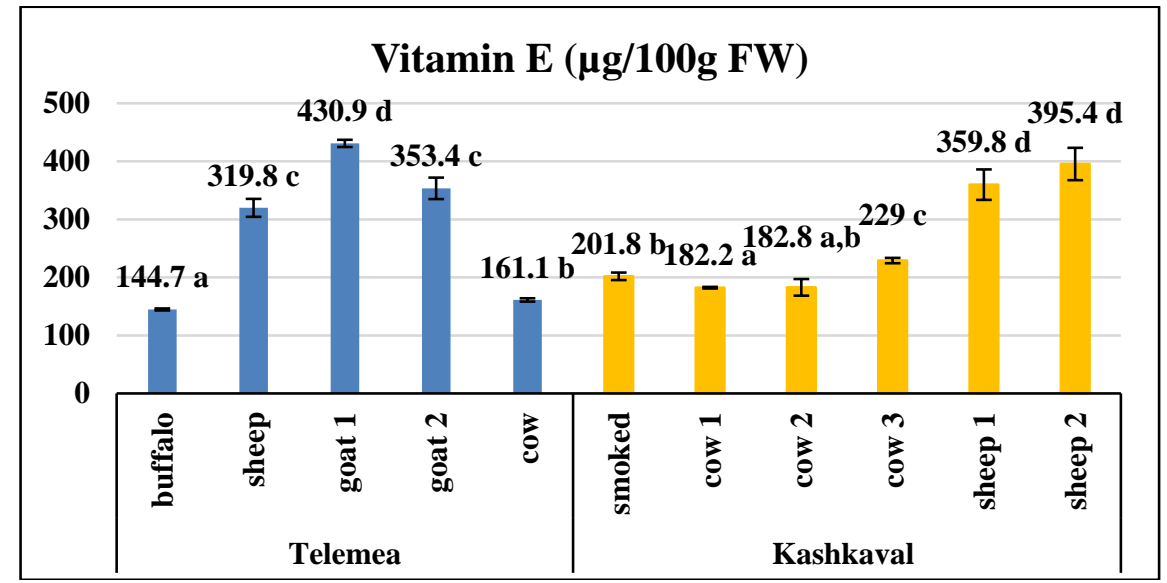

Figure 5. Content in vitamin $\mathrm{E}$ in the selected types of cheese

Note: For each group averages $( \pm S D ; n=3)$ noted with the same letters are not significantly different $(\mathrm{p} \leq 0.05)$

The vitamin E content performed in the Telemea products indicated the lowest value in buffalo Telemea $(144.7 \pm 1.75 \mu \mathrm{g} / 100 \mathrm{~g} \mathrm{FW})$ and higher values in the two goat Telemea types $(353.4 \pm 18.5-430.9 \pm 6.2 \mu \mathrm{g} / 100 \mathrm{~g} \mathrm{FW})$ and in the sheep type $(319.8 \pm 15.45 \mu \mathrm{g} / 100 \mathrm{~g} \mathrm{FW})$ (Figure 5). In fact, as can be seen from the Figure 5, products obtained from sheep milk have higher values of $\alpha$-tocopherol, regardless of whether they are Telemea or Kashkaval: $395.4 \pm 27.85 \mu \mathrm{g} / 100 \mathrm{~g} \mathrm{FW}$ in Dobrogea type of Kashkaval (sheep 2) and 359.8 $\pm 26.25 \mu \mathrm{g} / 100 \mathrm{~g} \mathrm{FW}$ in the other sample of sheep's Kashkaval (sheep 1).

\section{Disscusions}

\section{Vitamin content of the analysed types of cheese}

As in the case of Telemea cheese, the Kaskaval types obtained from cow milk register lower values of vitamin B1 content (between $31.12 \pm 0.99$ and $52.38 \pm 1.80 \mu \mathrm{g} / 100 \mathrm{~g}$ FW), being exceeded by those obtained from sheep milk $(56.48 \pm 0.98 \mu \mathrm{g} / 100 \mathrm{~g} \mathrm{FW}$ in sheep $1 \mathrm{Kashkaval}$, as well as $62.82 \pm 1.03 \mu \mathrm{g} / 100 \mathrm{~g} \mathrm{FW}$ in Dobrogea Kashkaval (sheep 2).

Among the Kashkaval types the lowest vitamin B1 content was found in smoked Kashkaval, being probably influenced by the production technology. Processing conditions as temperature, presence of oxygen, light and duration of heat treatment cause variable losses of vitamins according to the used method and type of food. The most labile vitamins during culinary processes are retinol, vitamin C, folate and thiamin (REDDY, 1999; LESKOVA, 2006). So, thermal processing significantly reduces the content of thiamin but changes of vitamins in dairy products depending on the obtaining technology have not yet been sufficiently investigated.

Regarding the vitamin B2 content, according to other researchers, high amounts were found in the goat Telemea. It seems that the activity of some microorganisms such as Streptococcus thermophilus and Lactococcus lactis causes an increased riboflavin content in cheese made from goat milk (PACHECO DA SILVA, 2016).

Analysis performed on the Kashkaval types indicated that the Kashkaval obtained from sheep milk contains higher amounts of vitamin B2 than the one made from cow milk regardless of their brand. However, other authors noted a different riboflavin content in cheese depending on the type of cheese, so the obtaining technology and the origin of milk could influence this parameter. Thus, a study conducted in Italy on four types of cheese (Taleggio, Provolone, Pecorino Romano and Caciotta) revealed values ranging from $133 \mu \mathrm{g} / 100 \mathrm{~g}$ to $328 \mu \mathrm{g} / 100 \mathrm{~g}$ of vitamin B2 (PANFILI, 1995).

Studying the obtained results it seems that, unlike vitamin $\mathrm{B} 1$, the smoking process of cheese did not affect so much the content of vitamin B2, which is comparable or even higher than that of unsmoked Kashkaval types. Studies performed by other authors indicates that although vitamin losses can occur during food processing, particularly in those subjected to heat treatment (OTTAWAY, 2002), riboflavin is regarded as one of the most stable vitamins because both riboflavin and riboflavin-phosphate are stable to heat and atmospheric oxygen, especially in acidic media (GOLBACH, 2014).

Milk and dairy products are food categories which provide a significant dietary cobalamin intake (ZIRONI, 2014; EFSA NDA Panel, 2015).

Although the values recorded for vitamin B12 content are low in the local cheese, they fit within the existing variations in the literature. For example, investigating 120 cheese samples for vitamin B12 values between $0.49-0.93 \mu \mathrm{g} / 100 \mathrm{~g}$ were found by Aylin and Ayaz (2009). However, Zironi et al. (2014) analysing samples of milk, rennet, whey, ricotta cheese, curd, mozzarella cheese and caciotta cheese showed about 10 times higher vitamin B12 in whey and ricotta cheese than in the milk they are derived from, explainable by the tendency of cobalamin to 
concentrate in the proteic fractions along the cheese making process.

In fact, studying the values obtained for the types of cheese analyzed (Figure 3), it seems that cheese making technology influences the content of vitamin B12 because there are significant differences between the samples of cow Kashkaval (Penteleu, Rucar, Dalia) and also between the two samples of sheep Kashkaval.

The lowest values of vitamin A ( $\beta$-carotene) were obtained for Telemea cheese made from buffalo and goat milk, while the highest for cow Telemea. In fact, some authors mentioned that $\beta$-carotene is present in cow milk but absent in buffalo, goat and sheep milk (RAYNALLJUTOVAC, 2008; ULLAH, 2017a; ULLAH, 2017b) because these animals metabolize the carotenoids into vitamin A which will be found in milk. Therefore this is the reason why differences in color between bovine and smaller ruminant dairy products are observed (PARK, 2007).

For Kashkaval types, the amounts of $\beta$-carotene reached values between $10.98 \pm 0.92$ and $41.10 \pm 2.90 \mu \mathrm{g} /$ $100 \mathrm{~g} \mathrm{FW}$, which are generally higher than for Telemea cheese. The highest value was registered in smoked Kashkaval so it seems that the content in $\beta$-carotene was not affected by the smoking process but further investigations on this topic are necessary.

The differences observed between the $\beta$-carotene values determined in the analyzed cheeses can be explained by the different provenance of the milk, considering the fact that several authors have shown that the $\beta$-carotene present in the cheese depends almost exclusively on the $\beta$-carotene in milk (LUCAS, 2006); also the period of milking is important as the carotenoid content of milk is higher during the summer than in other seasons (HULSHOF, 2006).

The data obtained (Figure 5) reveal a much more limited variation of the vitamin E content in the analyzed samples, a variation that suggests more a correlation with the content of this analyte in the raw material (milk), than with the technological process applied for cheese-making. The Kashkaval types should be expected to have a higher vitamin $\mathrm{E}$ content than the Telemea cheese due to their lower water content. But, the maturation of the Kashkaval types occurs over a longer period of time, which suggests a possible loss of vitamin $\mathrm{E}$ by oxidative attack.

Contribution of the analyzed cheese to achievement of the vitamins NRVs (nutrient reference values, meaning EU guidance levels on the daily amount of vitamin that the average healthy person needs to prevent deficiency).

Cheese cannot be considered valuable source of vitamins, its nutritional importance deriving from other biochemical components. However, the fact that these products contain vitamins, both water-soluble and fat-soluble, in measurable quantities, indicates their contribution to achieving daily doses that ensure the maintenance of human health.

According to European directives (Regulation EU No $1169 / 2011), 1.1 \mathrm{mg}$ is the recommended daily dose (NRV) for vitamin B1. In this context, it can be calculated a maximum intake of $2 \%$ of NRV of vitamin B1 achieved by consuming $100 \mathrm{~g}$ of Telemea cheese, while Kashkaval can bring an intake of vitamin B1 of up to $6 \%$ of NRV per $100 \mathrm{~g}$ of product.

The recommended daily dose of vitamin B2 according to the same European directives is $1.4 \mathrm{mg}$. Analyzing the data from this point of view it can be noted that the intake of vitamin B2 achieved by consuming $100 \mathrm{~g}$ of Telemea cheese can be about $75 \%$ of NRV, while in the case of Kashkaval can be obtained an intake of up to $27 \%$ of NRV per $100 \mathrm{~g}$ of product consumed.

Regarding the vitamin B12, the daily dose for adults is $2.5 \mu \mathrm{g}$. The obtained results revealed that Telemea type cheeses do not bring a significant intake of vitamin B12, except for the cow Telemea which could contribute about $20 \%$ to achieve the recommended daily dose. Instead, the consumption of $100 \mathrm{~g}$ of Kashkaval could provide up to about $50 \%$ (Dobrogea sheep Kashkaval) of the daily requirement of vitamin $\mathrm{B} 12$.

\section{Conclusions}

All previous studies focused on the analysis of vitamin concentrations in milk and there are few references in the literature to the contents of these vitamins in cheeses. The present study reveals that high values of vitamin B2 and $\mathrm{E}$ in Telemea cheeses were registered, while Kashkaval types contain vitamins B1, B12 and A in higher amounts.

The highest values of vitamins B1, B2 and E were determined for cheese obtained from goat milk, followed by those from sheep milk, while the lowest values were observed for cheese types obtained from cow milk. Instead cow cheese is distinguished by a higher content of vitamin B12 and $A$ ( $\beta$-carotene).

Differences in vitamins content have been found between cheese made from milk of the same animal origin, which may indicate that, in addition to the breed of milk supplier, the concentration of vitamins in the final product may be influenced also by other factors related to both the milk as raw material (food, age of the animal, season etc.) and the process of cheese-making.

A large proportion of vitamins B2 and B12 nutrient reference values (NRVs) can be achieved by daily consumption of goat and cow Telemea. At the same time, sheep Kashkaval as part of the daily diet can bring most of the required amount of B2 and B12 vitamins.

In conclusion, investigated dairy products had satisfactory nutritional value with respect to vitamins so consumption of different type of cheese may help humans to achieve the recommended daily intake of vitamins and supply health benefits.

\section{Acknowledgements}

This work was supported by ADER MADR 2020 Programme, project 14.1.1./2017.

\section{Conflict of Interest}

The authors have no conflict of interest to declare. 


\section{References}

1. AYLIN KD, AYAZ ND. Levels of vitamin B12 and folic acid in different cheese types. Veteriner Fakültesi dergisi. 2009; 56(3):187-191.

2. BALAN D, LUTA G, GHERGHINA E, ISRAELROMING F, MIHOCIU T. Method for determination of provitamin A in meat based samples. Sci. Bull. Series F. Biotechnologies. 2014; XVIII:97-100.

3. BRATU A, MIHALACHE M, HANGANU A, CHIRA NA et al. Gas Chromatography Coupled with Chemometric Method for Authentication of Romanian Cheese. Rev. Chim. 2012; 63(11):1099-1102.

4. EFSA NDA Panel (EFSA Panel on Dietetic Products Nutrition and Allergies), Scientific Opinion on Dietary Reference Values for cobalamin (vitamin B12). EFSA J. 2015; 13(7):4150 pp. 64.

5. FOX PF, GUINEE TP, COGAN TM, MCSWEENEY PLH. Fundamentals of Cheese Science, second edition by Springer New York, 2017. doi: 10.1007/978-14899-7681-9

6. GARDNER N, CHAMPAGNE CP. Production of Propionibacterium shermanii biomass and vitamin B12 on spent media. Journal of Applied Microbiology. 2005; 99: 1236-1245. doi: 10.1111/j.1365-2672

7. GHERGHINA E, ISRAEL-ROMING F, BALAN D, LUTA G, SIMION V, ZACHIA M. Assessment of some nutrients in bakery products, Scientific Bulletin. Series F. Biotechnologies, 2015: vol. XIX, 140-144

8. GILLE D, SCHMID A. Vitamin B12 in meat and dairy products. Nutr Rev. 2015; 73(2):106-15.

9. GOLBACH JL, RICKE S, O’BRYAN C, CRANDALL PG. Riboflavin in Nutrition, Food Processing, and Analysis - A Review. Journal of Food Research. 2014; 3(6): 23-35. doi:10.5539/jfr.v3n6p23

10. GÓRSKA-WARSEWICZ H, REJMAN K, LASKOWSKI W, CZECZOTKO M. Milk and Dairy Products and Their Nutritional Contribution to the Average Polish Diet. Nutrients. 2019; 11(8): 1771.

11. HULSHOF PJM, ROEKEL-JANSEN T, BOVENKAMP $P$, WEST CE. Variation in retinol and carotenoid content of milk and milk products in The Netherlands. J. Food Compos. Anal. 2006; 19(1): 67-75.

12. KWAK HS, GANESAN P, HONG Y. EDITORS: RICHARD D. Foster, Nutritional Benefits in Cheese. In book: Cheese:Types, Nutrition and Consumption, Nova Science Publishers, New York, USA, 2012.

13. LAIÑO JE, JUAREZ DEL VALLE M, SAVOY DE GIORI G, LEBLANC JG. Development of a high folate concentration yogurt naturally bio-enriched using selected lactic acid bacteria. LWT Food Sci. Technol. 2013; 54: 1-5.

14. LESKOVA E, KUBIKOVA J, KOVACIKOVA E, KOSICKA $M$ et al. Vitamin losses: Retention during heat treatment and continual changes expressed by mathematical models. J. Food Compos. Anal. 2006; 19(4): 252-276.

15. LEVIT R, SAVOY DE GIORI G, DE MORENO DE LEBLANC A, LEBLANC JG. Evaluation of the effect of soymilk fermented by a riboflavin-producing Lactobacillus plantarum strain in a murine model of colitis. Benef. Microbes. 2016; 8(1): 65-72. doi: org/10.3920/BM2016.0063

16. LINARES DM, GÓMEZ C, RENES E, FRESNO JM et al. Lactic Acid Bacteria and Bifidobacteria with Potential to Design Natural Biofunctional HealthPromoting Dairy Foods. Front. Microbiol. 2017; 8: 846.

17. LUCAS A, AGABRIEL C, MARTIN B, FERLAY A et al. Relationships between the conditions of cow's milk production and the contents of components of nutritional interest in raw milk farmhouse cheese. Lait. 2006; 86(3): 177-202. doi: 10.1051/lait:2005049

18. ÖSTE R, JÄGERSTAD M, ANDERSSON I, EDITOR PATRICK F. Fox, Vitamins in Milk and Milk products, In book: Advanced Dairy Chemistry, Volume 3, Chapman and Hall Publishers, London, 1997.

19. OTTAWAY PB, Editor HENRY CJK, CHAPMAN C. The stability of vitamins during food processing, In book: The Nutrition Handbook for Food Processors, CRC Press, Boca Raton, FL 2002.

20. PACHECO DA SILVA FF, BISCOLA V, LEBLANC GJ, GOMBOSSY DE MOLO FRANCO BD. Effect of indigenous lactic acid bacteria isolated from goat milk and cheeses on folate and riboflavin content of fermented goat milk, LWT-Food Sci Technol. 2016; 71: 155-161. doi: 10.1016/j.lwt.2016.03.033

21. PANFILI G, FALASCA L, MANZI P, PIZZOFERRATO L. Riboflavin in Milk and Dairy Products: A Methodological Study Atti del 2 Congresso Nazionale di chimica degli Alimenti, Giardini Naxos Italy. 1995.

22. PARK YW, JUAREZ M, RAMOS M, HAENLEIN GFW. Physico-chemical characteristics of goat and sheep milk. Small Rumin. Res. 2007; 68: 88-113. doi: 10.1016/j.smallrumres.2006.09.013

23. PUYOL P, PEREZ MD, ENA JM, CALVO M. Interaction of $\beta$-lactoglobulin and other bovine and human whey proteins with retinol and fatty acids. Agric. Biol. Chem. 1991; 55(10): 2515-2520. doi: org/10.1271/bbb51

24. RABAH H, ROSA DO CARMO FL, JAN G. Dairy Propionibacteria: Versatile Probiotics. Microorganisms. 2017; 5(2): 24. doi: 10.3390/microorganisms5020024

25. RAYNAL-LJUTOVAC K, LAGRIFFOUL G, PACCARD P, GUILLET I et al. Composition of goat and sheep milk products: an update. Small Rumin. Res. 2008; 79(1): 57-72. doi: 10.1016/j.smallrumres. 2008.07.009 
26. REDDY MB, LOVE M, EDITORS: JACKSON LS, KNIZE MG, MORGAN JN. The Impact of Food Processing on the Nutritional Quality of Vitamins and Minerals. In book: Impact of Processing on Food Safety. Advances in Experimental Medicine and Biology, vol 459. Springer, Boston, MA. 1999.

27. Regulation (EU) No 1169/2011 of the European Parliament and of the Council on the provision of food information to consumers, amending Regulations (EC) No 1924/2006 and (EC) No 1925/2006 of the European Parliament and of the Council (https://eurlex.europa.eu/legal-content/en/TXT/?uri=CELEX\% 3A32011R1169).

28. SANDERS ME. Overview on functional foods: Emphasis on probiotic bacteria. Int Dairy J. 1998; 8(5-6): 341-347. doi: org/10.1016/S0958-6946(98) 00056-9

29. SANTA D, SRBINOVSKA S. Traditional production and main characteristics of Galichki kashkaval. Mljekarstvo/Dairy. 2014; 64(2):119-126.

30. STANTON C, ROSS RP, FITZGERALD GF, SINDEREN DV. Fermented functional foods based on probiotics and their biogenic metabolites. Curr Opin Biotechnol. 2005; 16(2): 198-203. doi: 10.1016/ j.copbio.2005.02.008

31. ULLAH R, KHAN S, ALI H, BILAL $M$ et al. Identification of cow and buffalo milk based on beta-carotene and vitamin A concentration using fluorescence spectroscopy. Plos One. 2017a; 12(5): e0178055/
32. ULLAH R, KHAN S, ALI H, BILAL M et al. Ramanspectroscopy-based differentiation between cow and buffalo milk. J Raman Spectrosc. 2017b; 48(5): 692696. doi: org/10.1002/jrs.5103

33. VAN WYK J, WITTHUHN RC, BRITZ TJ. Optimisation of vitamin B12 and folate production by Propionibacterium freudenreichii strains in kefir. Int. Dairy J. 2011; 21(2): 69-74.

34. VOROBJEVA LI, KHODJAEV EYU, VOROBJEVA NV. Propionic acid bacteria as probiotics, Microb. Ecol. Health Dis. 2008; 20(2): 109-112. doi: org/10.1080/08910600801994954

35. YANG H, XIAO X, ZHAO X, HU L et al. Study on Fluorescence Spectra of thiamin and Riboflavin. 3rd International Conference on Material, Mechanical and Manufacturing Engineering, Published by Atlantis Press, 2015; 1458-1466.

36. ZAHAR M, SMITH DE, MARTIN F. Vitamin A distribution among fat globule core, fat globule membrane, and serum fraction in milk. J Dairy Sci. 1995; 78(3): 498-505.

37. ZIRONI E, GAZZOTTI T, BARBAROSSA A, FARABEGOLI F et al. Determination of Vitamin B12 in Dairy Products by Ultra Performance Liquid Chromatography-Tandem Mass Spectrometry, Ital J Food Saf. 2014; 3(4): 4513.

38. www.aoacofficialmethod.org/ AOAC 960.46-1960, Microbiological Methods. 